\title{
Kebijakan Berbasis Politik Rekognisi dan Resolusi Konflik Etnik
}

\author{
SUHARNO \\ Jurusan Pendidikan Kewarganegaraan dan Hukum FIS UNY \\ suharno@uny.ac.id
}

\begin{abstract}
Abstrak
Indonesia, sebagai negara multikultural, memiliki potensi konflik yang tinggi diantara unsur pembentuk multikulturalisme nya. Dalam konteks politik terpusat, Kotawaringin Timur (Kotim) terbukti sukses dalam resolusi konflik etnis, yaitu konflik Sampit antara suku Dayak dan Madura pada tahun 2001. Konflik tersebut diselesaikan tanpa meninggalkan beberapa masalah yang signifikan. Berbeda dengan daerah lain misalnya Kalimantan Barat dan Ambon di mana resolusi konflik diintervensi oleh Jakarta, Kotim berhasil dengan memberlakukan Peraturan Daerah No 5 Tahun 2004 tentang Penanganan penduduk yang terkena dampak dari konflik etnis. Dalam Perda tersebut disebutkan hak-hak masing-masing pihak yang saling bertentangan diakui. Pengakuan politik harus diwujudkan atau termasuk dalam kebijakan publik (pemerintah atau negara), sehingga masing-masing pihak mendapatkan kepastian hukum. Dalam mempersiapkan kebijakan publik diperlukan partisipasi masing-masing kelompok sehingga produk kebijakan tersebut dapat dipahami dan diterima oleh semua kelompok. Pelaksanaan Peraturan melibatkan partisipasi maksimum warga, tokoh masyarakat dan anggota Pemerintah Daerah.
\end{abstract}

Kata Kunci: peraturan daerah, resolusi konflik, pengakuan politik

\begin{abstract}
Indonesia, as a multicultural country, has a high potential of conflicts among forming elements of its multiculturalism. In the context of centralized politics, East Kotawaringin (Kotim) has succeeded performing ethnic conflict resolution namely Sampit conflict between Dayak and Maduranese in 2001. The conflict was resolved without leaving some significant problems. Different from other regions e.g. West Borneo and Ambon where conflict resolutions were intervened by Jakarta. Kotim succeeded in issuing Regional Regulation No 5 Year 2004 on Handling the citizens affected from the Ethnic Conflicts. The Regional Regulation has mentioned that the rights of each conflicting party are recognized. Political recognition must be realized or included in a public policy, so that each party obtain legal certainty. In preparing a public policy, the participation of each group is required so that the policy can be understood and accepted by all groups. The implementation of the Regulation involved maximum participation of citizens, community leaders and members of Local Government.
\end{abstract}

Keywords: Regional regulation, conflict resolution, political recognition 


\section{PENDAHULUAN}

Indonesia, sebagai negara multikultural, menghadapi potensi konflik yang tinggi antar elemen pembentuk multikulturalismenya. Anasir konflik dapat bermula dari persoalan perbedaan identitas hingga perjuangan pemenuhan kepentingan dan kebutuhan masing-masing. Elemen identitas yang berbeda berupa etnis, agama, adat istiadat, bahasa dan lain-lainnya secara alamiah merupakan penanda keberagaman yang secara sosial dapat memunculkan friksi atau gesekan. Agar minimalisasi potensi konflik dimungkinkan diperlukan ruang koeksistensi (space of coexistence) bagi sebagian besar identitas. Negara, sebagai institusi yang mengikat, memaksa, dan mencakup semua (all-encompassing, all-embracing)(Laski, 1947: 8-9; Budiharjo, 1996: 40-41), seharusnya mampu menghadirkan kebijakan yang memberikan ruang itu. Intervensi kebijakan dapat diambil dalam tiga ranah: prevensi, kurasi, dan preservasi.

Persoalannya dalam banyak kebijakan negara menonjol politik monokultural, bahkan sejak sebelum Indonesia menjadi. Pendekatan monokultural diambil untuk semata-mata stabilitas dan integrasi sosial. Politik monokulturalisme juga dilakukan Pemerintah Orde Baru. Politik monokulturalisme telah menghancurkan localcultural geniuses seperti tradisi "pela gandong" di Ambon, nagari di Sumatera Barat dan lainlain, diantaranya melalui Undang-Undang No. 5 tahun 1974 tentang Pemerintahan di Daerah yang menyeragamkan struktur desa di seluruh Indonesia seperti struktur desa di Jawa. Padahal, struktur desa yang dimiliki beberapa masyarakat tertentu seperti sistem pemerintahan nagari di Sumatera Barat, pemerintahan marga di Sumatera Selatan, pemerintahan Saniri di Maluku, tidak hanya mengandung sistem pelayanan administrasi namun juga pelayanan adat, dan bahkan memiliki mekanisme resolusi jika terjadi konflik (Ferdinand, 2005: 3).

Kebijakan politik monokulturalisme mempersempit ruang koeksistensi antar berbagai elemen multikultural. Dengan demikian, kebijakan tersebut menambah potensi alamiah konflik dengan bobot poli- tis, apalagi kebijakan monokultural tersebut diinstrumentasi dengan sentralisme, dan bahkan otoritarianisme. Dari sisi kebijakan, perpaduan antara kebijakan monokultural dan kegagalan otoritarianisme negara mengawal kebijakan tersebut merupakan salah satu faktor penting yang memicu, memendam energi, atau membiarkan berlarut-larut berbagai konflik antar identitas kultural atau konflik multikultural atau multietnik.

Pembahasan kajian ini mengkonstruksi benang merah di antara beberapa konsep pokok berikut: multikulturalisme, konflik, politik rekognisi dan kebijakan publik. Kajian atas empat konsepsentral tersebut memberikan perspektif teoretik yang utuh untuk memahami pembahasan tema sebagimana dimaksud.

\section{MULTIKULTURALISME DAN KONFLIK}

Masyarakat multikultural merupakan masyarakat yang komponennya menggambarkan lebih dari satu unsur, kultur-sub kultur, budaya, keyakinan, sistem keyakinan, agama dan lain-lain. Benang merah dan konteks dengan kajian ini adalah bahwa multikulturalisme merupakan konsep pengelolaan masyarakat yang secara kultural majemuk, sekecil apapun tingkat dan lingkup kemajemukan budaya tersebut, dengan memberikan pengakuan (rekognisi) atas eksistensi komponen kemajemukan tersebut. Pengakuan tersebut dalam fenomena kontemporer merupakan tuntutan (demand). Oleh karenanya ketiadaan pengakuan, yang berarti nihilnya pemenuhan tuntutan, sangat potensial terhadap munculnya berbagai konflik.

Masyarakat multikultural mengandung potensi konflik. Konflik terjadi karena masyarakat tersebut mengandung berbagai kepentingan, lembaga, organisasi, dan kelas sosial yang tidak selalu memiliki kepentingan yang sama dan serasi. Konflik bisa disebabkan oleh banyak hal.Konflik dapat disebabkan oleh polarisasi sosial yang memisahkan masyarakat berdasarkan penggolonganpenggolongan tertentu dapat menyebabkan timbulnya ketidakpercayaan dan permusuhan antar kelompok yang berbeda dalam masyarakat yang dapat berujung pada mun- 
culnya kekerasan yang terbuka.

Peristiwa konflik multikultur juga terjadi di Sampit Kotawaringin Timur (Kotim) Kalimantan Tengah yang melibatkan warga Etnis Madura dan Etnis Dayak. Dalam konflik ini ratusan bahkan ribuan penduduk dinyatakan tewas, kebanyakan warga Madura. Konflik juga mengakibatkan arus pengungsian sekitar 55.323 jiwa yang menimbulkan penelantaran, terbukti dengan meninggalnya 357 pengungsi, meluasnya wabah penyakit, kualitas hidup yang buruk serta sanitasi yang tidak memadai. Dampak luas yang terjadi berupa suasana ketakutan, trauma psikologis, dan ribuan warga yang kehilangan harta (Tempointeraktif, 16 Juli 2001).

Konflik antar etnik sebagaimana terjadi di Sampit dan Sambas membutuhkan penanganan komprehensif sebab bisa menjalar ke daerah lain. Peristiwa konflik multikultur yang terjadi di Sampit ditengarai juga tidak lepas dari peristiwa-peristiwa yang terjadi di Sambas (Surata dan Adrianto, 2001: 35). Konflik yang destruktif mengganggu proses integrasi bangsa. Untuk itu, diperlukan upaya penyelesaian konflik antar etnis secara lebih permanen, bukan penyelesaian-penyelesaian yang "hanya sering lebih bernuansa politis" sehingga justru masih sering menyisakan masalah-masalah yang dapat berkembang menjadi bibit konflik baru.

Konflik pada masyarakat multikultural bisa disebabkan oleh banyak hal. Konflik dapat disebabkan oleh polarisasi sosial yang memisahkan masyarakat berdasarkan penggolongan-penggolongan tertentu. Konflik tidak dapat dipisahkan dari kehidupan sosial.Terjadinya konflik juga tidak terelakkan dalam masyarakat.Masyarakat dipandang sebagai struktur sosial yang mencakup prosesproses asosiatif dan disasosiatif yang hanya dapat dibedakan secara analisis. Lebih lanjut dia mengatakan bahwa konflik merupakan pencerminan pertentangan kepentingan dan naluri untuk bermusuhan (Suharno, 2006: 3-4).

Schmeidl dan Jenkins (1998: 66) mengkategorikan konflik etnik sebagai konflik dengan karakter tertentu memiliki penyebab yang kompleks. Penyebab tersebut dapat dikemukakan berbagai faktor sebagai berikut: Pertama, faktor sosial ekonomi; a) saling mengklaim dalam menguasai sumber daya yang terbatas. b) kecemburuan sosial yang bersumber dari ketimpangan ekonomi antara kaum migran (pendatang) dengan penduduk asli (lokal). Kedua adalah faktor sosial budaya; a) dorongan emosional kesukuan, b) sentimen antar pemeluk agama yang terjadi. Ketiga adalah faktor sosial politik; a) distribusi kekuasaan yang tidak merata. b) tidak tunduknya individu atau kelompok sebagai pihak yang dikuasai terhadap sanksi yang diberikan oleh pihak yang sedang berkuasa. c) ketegangan antara kelompok yang sedang berkuasa dengan kelompok yang dikuasai. Dalam studi konflik, dikenal beberapa konsep dasar yang mengkerangkai bagaimana respon atas konflik atau potensi konflik, antara lain: manajemen konflik, transformasi konflik, dan resolusi konflik.

Dalam kajian ini-sebagai studi kebijakan, sesuai dengan background keilmuan peneliti-penggunaan konsep penyelesaian konflik digunakan untuk menjembatani konsep teoretik dalam studi konflik dengan istilah legal dalam kebijakan publik, yang seringkali bersifat lebih teknikal, seperti penanganan. Secara substantif konsep penyelesaian konflik dalam penelitian ini berdekatan dengan konsep resolusi konflik dalam studi konflik.

\section{POLITIK REKOGNISI}

Eksistensi sebagai suatu negara yang multikultural dengan potensi konflik yang sedemikian besar dan ancaman terjadinya eskalasi menuju ke arah pertentangan dengan intensitas yang lebih tinggi hingga terjadi kekerasan mengharuskan adanya saluran yang tepat. Dengan demikian kondisi multikulural tersebut bisa terjembatani sehingga konflik yang terjadi bersifat sinergi bukan sebaliknya bersifat korosi dan menghancurkan tatanan kehidupan bernegara.

Politik rekognisi merupakan konsep yang relatif baru, yang bermakna pengakuan dari pihak yang mayoritas kepada pihak yang minoritas dan tidak teruntungkan sedang 
pengakuan tersebut dituangkan di dalam sebuah aturan hukum yang mengikat. Kajian ini berusaha mengadaptasi konsep politik rekognisi dalam kebijakan publik. Teori Charles Taylor mengenai politik rekognisi yang secara filosofis diinspirasi oleh Hegel dan Honneth.Pada mulanya, politik rekognisi berangkat dari kajian filsafat, budaya dan politik identitas. Kajian filsafat yang menonjol mengenai rekognisi diajukan oleh Hegel (1977 lewat Douzinas, 2002: 380). Pentingnya penerapan politik pengakuan (politics of recognition) yang dapat menjadi landasan bagi terciptanya kebersamaan di antara berbagai budaya, kelompok etnis, ras dan agama. Sebab tak adanya pengakuan adalah penindasan (misrecognition is an oppression)(Anderson, 2009: 37-45; Lovell, 2007: 2-3).

Dalam perspektif ini, pengakuan bukan hanya sekedar suatu kebaikan yang berlaku dalam diri. Pengakuan adalah kebutuhan vital manusia. Kesalahan pengakuan dapat menunjukkan adanya kesenjangan yang dapat menyebabkan luka yang mendalam, membebani korbannya dengan tekanan batin yang menyiksa. Menambahkan gagasan Taylor, Andersson menyatakan bahwa hakikat politik rekognisi pada perkembangannya adalah politik rekognisi etnik (Azra lewat Lovell, 2007: 2-3).

Pentingnya penekanan prinsip-prinsip politik rekognisi dalam penyelesaian secara permanen konflik multietnik ini karena keunikan dari sifat konflik yang tajam dan bervariasi antara pihak-pihak, sehingga sulit diselesaikan dengan cara-cara sederhana, seragam, dan menegasikan perbedaan para pihak tanpa keterlibatan mereka. Politik rekognisi menekankan adanya itikad baik dari pihak yang dominan untuk memberi pengakuan kepada pihak-pihak yang secara hak dan kedudukan dicap sebagai minoritas atau disadvantaged groups. Dengan adanya pengakuan ini, hak dan kedudukan kelompok minoritas diakui dan dapat diangkat sehingga setara dengan kelompok dominan atau hanya sampai batas-batas tertentu yang diberikan pengakuan.

\section{KEBIJAKAN PUBLIK}

Langkah efektif untuk mewadahi politik rekognisi adalah mengadopsinya dalam produk hukum perundang-undangan atau kebijakan publik yang dikeluarkan oleh pejabat formal. Efektivitas kebijakan publik dalam mewadahi prinsip-prinsip politik pengakuan karena pejabat formal merupakan bagian integral dari negara yang memiliki alat pemaksa untuk berlakunya kebijakan publik tersebut sehingga kebijakan tersebut dapat dijalankan.

Namun demikian, perumusan masalah kebijakan dalam analisis kebijakan adalah bagian yang bersifat krusial. Kegagalan analisis kebijakan sering dikarenakan oleh analisis atau policy maker justru memecahkan masalah yang salah. Penyebab kegagalan yang lain adalah solusi yang diajukan salah atau kurang tepat dalam memecahkan suatu masalah yang benar-benar masalah.

Kebijakan publik adalah: "political sagacity, statecraft, prudent conduct, craftiness, course of action adopted by government, party, etc." (Wayne, 2006: 22). Chandlerdan Plano(1988, lewat Tangkilisan, 2003: 13) menjelaskan, kebijakan publik ialah pemanfaatan yang strategis terhadap sumberdayasumberdaya yang ada untuk memecahkan masalah-masalah publik atau pemerintah. Kebijakan publik merupakan bentuk intervensi yang dilakukan secara terus-menerus oleh pemerintah demi kepentingan kelompok yang kurang beruntung dalam masyarakat agar mereka dapat hidup, dan ikut berpartisipasi dalam pembangunan secara luas.

Pengertian kebijakan publik sebagai bentuk intervensi pemerintah dalam mengatasi persoalan publik yang terjadi di dalam masyarakat sangat tepat untuk memahami mengapa pemerintah daerah Kotim mengeluarkan Perda untuk mengatasi persoalan yang terjadi di daerah tersebut. Pemerintah melalui kebijakan publik yang diambilnya ingin mengakui dan memaksa kelompok mayoritas untuk mengakui (merekognisi) kelompok-kelompok lain yang minoritas. Dengan adanya kebijakan tersebut maka kelompokkelompok yang selama ini tidak terakomo- 
dasi karena kecilnya suara mereka, memiliki saluran untuk menunjukkan eksistensi mereka dan diakui sebagai bagian dari masyarakat secara utuh. Konflik etnik di Kotim merupakan persoalan yang sangat urgen untuk diselesaikan dengan pendekatan kebijakan yang tepat karena konflik etnis sebagaimana yang terjadi di Kotim maupun di daerah-daerah lain merupakan suatu masalah yaitu suatu kondisi atau situasi yang menimbulkan kebutuhan atau ketidakpuasan pada sebagian orang yang menginginkan pertolongan atau perbaikan (Winarno, 1989: 49).

\section{KEBIJAKAN REKOGNITIF SEBAGAI IN- STRUMEN RESOLUSI KONFLIK ETNIS}

Konflik etnis di wilayah Kotim merupakan sebuah masalah publik karena masyarakat atau suku-suku/etnis yang ada di Kotim menganggap bahwa permasalahan yang terjadi di antara mereka adalah permasalahan yang tidak dapat diterima dan dibiarkan karena berakibat buruk dan serius terhadap keberadaan mereka dan bahkan mengancam sendi-sendi ketahanan nasional. Ini sejalan dengan pendapat yang mensyaratkan, suatu masalah akan menjadi masalah apabila ada orang atau kelompok yang menggerakkan ke arah tindakan guna mengatasi masalah tersebut (Winarno, 1989: 50). Sebagai masalah publik, konflik etnik meniscayakan penyelesaian dengan kebijakan publik pula.

Dalam sistem hukum Indonesia, kebijakan publik yang bersifat mengikat masyarakat dan membebankan kewajiban tertentu kepada rakyat wajib dituangkan dalam bentuk Undang-Undang di tingkat nasional dan Peraturan Daerah di tingkat daerah baik di tingkat Provinsi maupun tingkat Kabupaten/Kota. Ketentuan ini mengandung maksud agar dalam penyusunan kebijakan publik tersebut masyarakat dilibatkan antara lain melalui wakil-wakil rakyat di DPR dan DPRD. Selain itu, untuk berbagai masalah yang sangat mendasar, keterlibatan masyarakat masih diharapkan melalui public hearing.

Dalam konteks konflik etnis di Sampit Kotim, bagaimana pendekatan kebijakan untuk menangani konflik tersebut? Pemerintah
Daerah Provinsi Kalimanatan Tengah sempat mengeluarkan peraturan yang isinya mengatur tentang larangan bagi Etnis Madura untuk masuk wilayah Kalbar maupun Kalteng. Namun Perda tersebut tidak bertahan lama dan mengalami revisi ketika Etnis Madura yang datang ke Kalteng menunjukkan sikap-sikap asimilasi yang signifikan. Pada akhirnya, Pemprov Kalteng menerbitkan Perda No. 9 Tahun 2003 tertanggal 6 November 2004 tentang Penanganan Penduduk Dampak Konflik Etnik. Terbitnya Perda diikuti dengan lahirnya Perda Kabupaten Kotim yaitu Perda No. 5 tahun 2004 tertanggal 8 Juli 2004 tentang Penanganan Penduduk Dampak Konflik Etnik. Kurang lebih setahun sebelumnya atau tepatnya 26 Juli 2003, Pemda Kabupaten Kapuas telah terlebih dulu menerbitkan Perda, yang isinya kurang lebih sama, tentang Penyelenggaraan Pengembalian Pengungsi Dampak Konflik Etnik.

Kasus yang terjadi di Sampit Kalteng ini menarik untuk dikaji lebih mendalam khususnya mengenai peranan politik, khususnya politik pengakuan (politik rekognisi),dalam mengembalikan harmoni sosial, serta pengaruh politik pengakuan tersebut dapat mengeliminasi dan meminimalisasi potensi konflik yang dapat terulang jika keberagaman tidak dikelola secara cerdas dan bijaksana. Konflik multietnis di Kalteng memang tidak repetitif seperti konflik di Kalbar, namun tingkat kengerian dan kekejaman konflik diakui oleh banyak kalangan sebagai konflik terkejam. Selain itu, respons Pemprov Kalteng, Pemkab Kotim dan Pemkab Kapuas dengan menerbitkan Perda penanganan konflik merupakan upaya yang layak diapresiasi dan dikaji.

Pentingnya penekanan prinsip-prinsip politik rekognisi dalam penyelesaian secara permanen konflik multietnik ini karena keunikan dari sifat konflik yang tajam dan bervariasi antara pihak-pihak, sehingga sulit diselesaikan dengan cara-cara sederhana, seragam, dan menegasikan perbedaan para pihak tanpa keterlibatan mereka. Politik rekognisi menekankan adanya itikad baik dari pihak yang dominan untuk memberi pengakuan kepada pihak-pihak yang secara 
hak dan kedudukan dicap sebagai minoritas atau disadvantaged groups. Dengan adanya pengakuan ini, hak dan kedudukan kelompok minoritas diakui dan dapat diangkat sehingga setara dengan kelompok dominan atau hanya sampai batas-batas tertentu yang diberikan pengakuan.

Hal tersebut sangat berbeda dengan penyelesaian konflik antar etnis yang selama ini sering dilaksanakan dalam bentuk keputusan politik melalui DPRD berupa Perda yang sering menegasikan keterlibatan pihak-pihak yang ini memuat judul Peraturan Daerah tentang Penanganan Penduduk Dampak Konflik, namun dalam perspektif lebih luas, inilah salah satu bentuk kebijakan publik yang dituangkan dalam peraturan perundangan yang secara khusus menampung dan mengakui adanya keragaman sekaligus mengandung niat dari pihak-pihak yang mayoritas untuk mengakui (merekognisi) pihak-pihak pendatang yang minoritas. Hal ini antara lain tercermin dalam Pasal 2 yang menyatakan "Pengembalian penduduk berdasarkan kesetaraan sebagai anak bangsa, untuk hidup berdampingan secara damai di Kalimantan Tengah" (Perda Kabupaten Kotawaringin Timur No 5 tahun 2004). Penelaahan terhadap latar, proses kelahiran, dan implementasi Perda ini akan menghadirkan pemahaman bagaimana politik rekognisi itu berjalan di daerah yang tidak hanya potensial terjadi konflik, tetapi telah berulangkali mengalami konflik. berkonflik dalam upaya penyelesaian konflik. Sekalipun Perda Nomor 5 Tahun 2004

Untuk menyelesaikan konflik yang terjadi dan untuk meredam potensi konflik yang ada maka dapat dilakukan dengan cara masingmasing pihak memahami posisinya dalam masyarakat multikultural tersebut sehingga mampu bersinergis dalam menciptakan harmonisasi suatu masyarakat multikultural. Pemahaman posisi etnis dalam suatu masyarakat multikultural pada hakikatnya merupakan jembatan menuju terjadinya suatu pengakuan dimana etnis dan budaya yang mayoritas berada dalam posisi untuk mengakui eksistensi dan hak hidup etnis dan budaya minoritas demikian sebaliknya.

Karena keberadaan suatu masyarakat multikultural tersebut tidak terlepas dari suatu ikatan kewilayahan dan tergabung dalam suatu negara tertentu maka suatu pengakuan akan etnis dan budaya masingmasing diwujudkan dalam suatu politik pengakuan dan lebih kongkrit lagi dalam suatu kebijakan publik yang menjamin bahwa pihak-pihak tersebut berkomitmen untuk melaksanakan cita-cita bersama tersebut. Jaminan mana dikuatkan dengan daya paksa yang dimiliki negara untuk menegakkan kebijakan publik tersebut.

Dengan demikian, titik kritisnya berada dalam proses perumusan, penyusunan dan implementasi kebijakan publik yang tepat sehingga posisi masing etnis dan budaya tersebut terpelihara dan tidak terjadi gesekan yang memicu konflik. Kesalahan atau kekurangtepatan dalam proses perumusan, penyusunan dan implementasi kebijakan publik dapat berakibat kepada goyahnya komitmen bersatu dan saling mengakui antar etnis dan budaya yang secara tiba-tiba dalam waktu yang relatif singkat dapat menuju terjadinya konflik terbuka secara fisik dan kekerasan bersenjata sebagaimana terjadi di Indonesia beberapa waktu belakangan salah

Prinsip-prinsip politik rekognisi telah terkonstruksi dalam Perda Kotim Nomor 5 tahun 2004 tentang Penanganan Penduduk Dampak Konflik Etnik dalam sifatnya yang sangat mendasar yaitu hak untuk hidup secara damai dan bertempat tinggal di Sampit bagi warga Madura sebagai etnis minoritas dan dalam posisi tidak diuntungkan. Hak-hak tersebut diakui oleh warga Etnis Dayak sebagai etnis mayoritas yang bertindak sebagai pemberi pengakuan sepanjang Etnis Madura menaati hukum yang berlaku, bersedia ikut menjunjung falsafah belom bahadat dan "dimana bumi dipijak disana langit dijunjung". Sementara Etnis Dayak diakui kedudukannya sebagai etnis asli yang memiliki tatanan sosial dan kemasyarakatan serta adat istiadat yang berlaku dan terpelihara serta mewajibkan setiap orang yang datang untuk menghormati dan menjunjung adat istiadat tersebut sepanjang menyangkut masalah sosial kemasyarakatan dan bukan ritual keagamaan. 
Perda mampu menyelesaikan konflik tidak bersenjata yang merupakan sisa-sisa masalah yang timbul setelah kerusuhan berdarah 18 Februari 2001 yang sejak dulu ada dan masih sangat potensial terjadi. Titik krusial siklus kebijakan dalam penyelesaian konflik etnik Sampit terletak pada tahap formulasi kebijakan, dimana konstruksi ketentuan-ketentuan legal yang akan mengikat kedua belah pihak yang berkonflik ditentukan. Proses penyusunan Perda cukup mewadahi critical point yang menentukan upaya keberhasilan perwujudan perdamaian. Hal tersebut karena proses penyusunannya dilakukan pada fase penenangan, memberi ruang dialog dan saluran aspirasi pihak-pihak yang bertikai, melalui proses musyawarah-musyawarah internal etnik dan antar etnik terlebih khusus Etnis Dayak dan Madura sebagai pihak yang berkonflik, dengan demikian bersifat bottom-up dan proses yang sangat partisipatif dari warga masyarakat, pengaturan-pengaturan yang termuat di dalamnya telah sesuai dengan tuntutan untuk menyelesaikan konflik. Disamping itu pemberlakuannya telah memberi kepastian secara yuridis formal untuk menjamin adanya perlindungan kepada setiap pihak yang berkonflik untuk perdamaian, hal itu juga yang mendorong pihak-pihak yang berada dalam pengungsian untuk berani pulang ke Sampit untuk hidup berdampingan kembali dengan penduduk sebagaimana sebelum terjadi konflik.

Implementasi Perda berjalan relatif lancar, adanya hambatan-hambatan terutama terletak pada proses pemulangan pengungsi Etnis Madura ke domisili semula sebelum terjadi konflik terkendala beberapa hal; data identitas diri yang sudah hilang atau rusak, warga tersebut tidak dikenal pengurus pemerintahan terendah (RT, RW), ataupun warga tersebut telah terlanjur mendahului pulang sebelum waktu yang sudah disepakati. Hambatan-hambatan tersebut dapat teratasi dengan langkah yang tetap berdasarkan Perda yakni pengecekan/pencocokan pada data kependudukan yang ada di Dinas Kependudukan dan Catatan Sipil. Ketika data-data minimal warga tersebut tetap dapat ditemukan maka warga tersebut tetap dii- jinkan kembali ke tempat tinggal semula sebelum terjadi konflik.

Keberhasilan implementasi Perda yang dilaksanakan pada fase settlement, dan efektivitas Perda dalam penyelesaian konflik tidak bersenjata karena sesungguhnya persoalan besar Perda ini telah selesai pada level formulasi kebijakan sedangkan implementasinya sudah menjadi persoalan yang relatif mudah. Perda ini merupakan formalisasi kesepakatan-kesepakatan yang telah menjadi kesepahaman antar pihak untuk saling menghormati, memberi dan menerima dari adanya tuntutan atas hak dan kewajiban masing-masing pihak yang berkonflik. Sehingga Perda yang sifatnya sangat bottom-up dan partisipatif sejak tahap formulasinya ini sangat memperoleh dukungan atau pengawalan dalam proses implementasinya oleh setiap pihak tersebut. Dapat dinyatakan di sini bahwa dalam tahapan kebijakan, maka proses formulasi kebijakan merupakan "hulu" yang sangat menentukan "hilir". Namun demikian, kehadiran Perda tetap mutlak diperlukan untuk memberi jaminan legalitas formal kepada setiap pihak dalam menaati kesepahaman tersebut.

Keberhasilan implementasi Perda juga telah mampu secara perlahan mengharmonisasi warga masyarakat multietnik dan multikulutral sehingga pada gilirannya mampu mempreservasi suasana perdamaian terbukti setelah 8 tahun pemberlakuannya, tidak terjadi konflik antar etnis di Sampit dan penyelesaian masalah ekses konflik telah dilaksanakan dengan baik.

\section{SIMPULAN}

Dari bahasan tersebut dapat dirumuskan beberapa kesimpulan sekaligus proposisi penting: 1) Titik krusial siklus kebijakan dalam penyelesaian konflik etnik terletak pada tahap formulasi kebijakan, dimana konstruksi ketentuan legal yang akan mengikat pihak-pihak yang berkonflik ditentukan. Peraturan yang sifatnya bottom-up dan partisipatif sejak tahap formulasi terbukti efektif pada tahap implementasi. Maka dalam tahapan kebijakan, proses formulasi kebijakan 
merupakan "hulu" yang sangat menentukan "hilir". 2) Politik monokultural sekalipun ditopang dengan kekuasaan yang besar tidak akan berhasil menyatukan masyarakat yang multikultural, baik dari sisi etnis, keyakinan, praktek keyakinan, dan gaya hidup, bahkan memendam potensi konflik yang dapat menjadi konflik terbuka dan bersenjata. 3) Dalam masyarakat multikultural, politik rekognisi merupakan instrumen utama untuk menjamin terwujudnya ruang ekspresi setiap identitas baik besar maupun kecil. 4) Politik rekognisi harus diwujudkan dalam suatu kebijakan publik (pemerintah atau negara), sehingga setiap pihak mendapatkan jaminan kepastian hukum. 5) Dalam penyusunan suatu kebijakan publik yang menyangkut hubungan antar kelompok dalam masyarakat multikultural diperlukan partisipasi dari setiap kelompok agar produk kebijakan dapat dipahami dan diterima oleh semua kelompok. 6) Intervensi kebijakan Pemerintah Pusat dalam menyelesaikan konflik antar etnik dan konflik multikultural lainnya tidak berkorelasi positif dengan penyelesaian konflik tersebut. Prakarsa dan porsi Pemerintah Daerah yang besar seperti di Kotim terbukti menunjukkan penyelesaian konflik yang lebih permanen, paling tidak bila dibandingkan dengan konflik serupa di Sambas, Ambon, dan Poso.

\section{UCAPAN TERIMA KASIH}

Pada kesempatan ini penulis mengucapkan terima kasih kepada dewan redaksi Jurnal Socia atas kesempatan yang diberikan sehingga paper ini dapat diterbitkan pada Jurnal Socia edisi Mei 2015.

\section{DAFTAR PUSTAKA}

Anderson. 2009.Hegel's Theory of Recognition: from Oppression to Ethical Liberal Modernity.London and New York: Continuum Books.
Budiharjo, M. 1996. Dasar-Dasar Ilmu Politik. Jakarta: Gramedia

Douzinas, C. 2002. "Identity, Recognition, Rights or What Can Hegel Teach Us About Human Rights?".Journal of Law and Society.Vol 29 No 3, hlm. 380

Ferdinand, C. 2005. Dinamika Masyarakat Patalima (Suku Bangsa Alune) Dalam Mempertahankan Budaya Lokal di Pulau Seram.Tesis Tidak Dipublikasikan. Universitas Gadjah Mada

Laski, H.J. 1947. The State in Theory and Practice. New York: The Viking Press

Lovell, T (ed.). 2007. (Mis)recognition, Social Inequality and Social Justice: Nancy Fraser and Pierre Bourdieu. London and New York: Routledge.

Perda Kabupaten Kotawaringin Timur No 5 tahun 2004 tentang Penanganan Penduduk Dampak Konflik Etnik

Scmeidl dan Jenkins, 1998. "Early Warning Indicators of Forced Indicators". dalam Davies dan Gurr (eds.). 1998. Preventive Measures: Building Risk Assessment and Crisis Early Warning Systems.Maryland, USA" Rowman and Littlefield Publishers Inc.

Suharno. 2006. "Konflik, Etnisitas, dan Integrasi Nasional". Makalah disampaikan dalam Seminar dan Lokakarya Resolusi Konflik pada Civics Community DIY. 18 dan 20 November 2006. Universitas Negeri Yogyakarta.

Surata, A. dan Adrianto, T.T. 2001. Atasi Konflik Etnis.Yogyakarta: Global Pustaka Utama dan UPN "Veteran".

Tangkilisan, H.N.S. 2003.Kebijakan Publik yang Membumi. Yogyakarta: Lukman Offset \& YPAPI

Wayne, P.2006. Public Policy. Pengantar Teori dan Praktik Analisis Kebijakan. Jakarta: Kencana Prenada Media Group

Winarno, B. 1989. Teory Kebijakan Publik. Yogyakarta: PAU-UGM 